\title{
I Have no Period, How can I Have Children: A Case of Mayer-Rokitansky-Kuster-Hauser Syndrome
}

\author{
Shantalasha Onika Knowles ${ }^{1 *}$ and Shamanique Shamona Bodie-Williams \\ Department of Obstetrics and Gynaecology, Bahamas Public Hospitals Authority, The Bahamas \\ Submission: February 20, 2017; Published: March 08, 2017
}

*Corresponding author: Shantalasha Onika Knowles, Department of Obstetrics and Gynaecology, Bahamas Public Hospitals Authority, P.O. Box N9580, The Bahamas, Tel: 242-557-5596; Email: onika_knowles@yahoo.com

\begin{abstract}
Mayer-Rokitansky-Kuster-Hauser Syndrome (MRKH) is not frequently encountered and when cases are seen it is imperative that the topic be revisited and shared with colleagues in order to grasp a good understanding of its management. In this case report we present a typical but delayed diagnosis in a 28 year old.
\end{abstract}

\section{Introduction}

Mayer-Rokitansky-Kuster-Hauser syndromeis a disorder characterized by the congenital absence of the upper two thirds of the vagina and an absent or rudimentary uterus in a phenotypical female (46XX). It affects approximately 1 in 4000 - 5000 live female births [1]. It is known by other names that include congenital absence of the uterus and the vagina, mullerian agenesis, mullerian aplasia or genital renal ear syndrome [2]. The syndrome is named for the persons that described and documented their findings over a period from 1829 -1965 [3]. Most physicians will only see this condition once or twice in their career. In this review we will describe the presentation, classification, associated abnormalities, current genetic associations and management options for improvement of sexual function in MRKH syndrome.

\section{Case Report}

A 28 year old nulliparous patient presented to the gynecology clinic with a complaint of amenorrhea. She noted that at the age of 18 years old she got concerned when she did not have a period and sought medical attention from a general practitioner. She recalls that at that time she had an ultrasound that revealed the presence of an "unusually small" uterus. It was unknown what additional testing was requested, but due to financial constraints, she defaulted. Her new concerns regarding the ability to conceive lead her to the gynecology clinic. Attempts at coitus were unsuccessful with an inability to achieve penile penetration. She never used contraception and was a non- smoker and did not consume alcohol. She had no prior surgeries or allergies. There was no cyclical abdominal or pelvic pain or changes reflecting cyclical hormonal variations. She had normal breast development and noted normal growth of pubic and axillary hair.

On examination, there was a young female of normal stature (5ft) with a body mass index of $22.26 \mathrm{~kg} / \mathrm{m} 2$. Blood pressure and pulse were normal. There were no obvious external anatomical abnormalities and she had normal female axillary hair and pubic hair distribution. Her breasts were symmetrical and normal with no nipple discharge seen. The external genitalia was phenotypically female with an annular hymen (clitoris and labia were normal). A small vaginal pouch was palpated on digital exam (only the fifth digit could be introduced, vaginal length was about $3 \mathrm{~cm}$ ). No female pelvic organs were palpated bimanually. Speculum exam (done with a nasal speculum as a vaginal speculum could not be inserted) revealed normal vaginal walls with a blind-pouch, and no cervix was visualized. She was assessed as primary amenorrhea with aims to fully elucidate the cause.

An abdominal, pelvic and renal ultrasound revealed normal organs including two kidneys that were normal in size and echopattern without hydronephrosis or calculi. The urinary bladder was well distended, with no abnormalities. There was no uterus seen. A right gonad was noted on the pelvic side wall that was suggestive of an ovary measuring $2.5 \mathrm{~cm} \mathrm{X} 1.7 \mathrm{~cm} \mathrm{X} 2.6 \mathrm{~cm}$ (no gonad was seen on the left). 
A hormonal profile, chromosomal analysis and a magnetic resonance imaging was requested. The patient did not do the MRI; however other test result were available (Table 1). The hormonal profile was normal and karyotype was $46 \mathrm{XX}$ (Table 1).

Table 1: Laboratory Results.

\begin{tabular}{|c|c|}
\hline Test & $\begin{array}{c}\text { Result ( Normal Value In } \\
\text { Parenthesis) }\end{array}$ \\
\hline Free Testosterone & $26 \mathrm{ng} / \mathrm{dl}(8-48)$ \\
\hline Total Testosterone & $<20.0 \mathrm{ng} / \mathrm{dl}(270-1734)$ \\
\hline Sex Hormone Binding Globulin & $78.4 \mathrm{nmol} / \mathrm{L}(24.6-122.0)$ \\
\hline Free Androgen Index & $1.2(0.4-8.4)$ \\
\hline DHEAS & $107(31-701$ based on age) \\
\hline Oestrogen & $\begin{array}{c}215 \mathrm{pg} / \mathrm{ml}(\text { Pre-pubertal }<40, \\
61-350 \mathrm{based} \text { on cycle days) }\end{array}$ \\
\hline Luteinizing Hormone (LH) & $\begin{array}{c}4.5 \mathrm{miu} / \mathrm{ml}(11.3-39.8, \text { however } \\
\text { based on day of cycle) }\end{array}$ \\
\hline Follicle stimulating hormone & $3.50 \mathrm{miu} / \mathrm{ml}(0.8-7.6)$ \\
\hline (FSH) & $140 \mathrm{mg} / \mathrm{dl}(136-145)$ \\
\hline Sodium & $3.9 \mathrm{mmol} / \mathrm{l} \mathrm{(3.50-5.1)}$ \\
\hline Potassium & $107 \mathrm{mmol} / \mathrm{l}(98-107)$ \\
\hline Chloride & $5 \mathrm{mg} / \mathrm{dl}(7-18)$ \\
\hline Blood Urea Nitrogen & $14.1 \mathrm{~g} / \mathrm{gl}(12-16.0)$ \\
\hline Haemoglobin & $39.9 \%(36-47)$ \\
\hline Haematocrit & $169 \mathrm{~K} / \mathrm{Ul}(140-420)$ \\
\hline Platelets &
\end{tabular}

The definitive diagnosis was mullerian agenesis. The patient was thoroughly counseled and options regarding management were discussed. She and her partner were comfortable with adoption, but noted that use of assisted reproductive technology and surrogacy would remain an option if desired. They wanted to be able to achieve coitus and the patient wanted to avoid any surgical intervention and therefore non-surgical creation of a neovagina was discussed which she agreed to. Vaginal dilators are currently being used in this patient for the same.

\section{Discussion}

MRKH Syndrome can present similar to other conditions that are also not commonly encountered. The differential diagnosis in these patients include (but is not limited to); imperforate hymen, transverse vaginal septum, androgen insensitivity syndrome (which is a 46XY disorder) and 17 alpha hydroxylase deficiency.

Most of these patients often present with primary amenorrhea but with developed secondary sexual characteristics [4-6]. Other presenting symptoms include the inability to have sexual intercourse as in the case above or dyspareunia or infertility [4].

\section{Classification}

The syndrome is divided into the following three classes;

\section{Typical MRKH (Type I)}

This has isolated symmetric absence of the vagina or hypo plastic uterus.

\section{Atypical MRKH(Type II)}

This has asymmetric uterovaginal absence or hypoplasia, absence or hypoplasia of one or both of the fallopian tubes and malformation in the ovaries and/or the renal system.

\section{MURCS (MUllerian agenesis, Renal Agenesis, Cervicothoracic Somite abnormalities)}

This classification has the above with the addition of a skeletal and or cardiac malformation, muscular weakness and renal malformation. The typical classification is the most common type followed by the atypical and MURCS.

\section{Embryology}

In females the mullerian ducts are present by the sixth week of development and continued development, migration and fusion during the twelfth week. Mullerian agenesis is caused by the embryologic failure of the mullerian duct and sinovaginal bulbs, as a result the vagina and uterus may not develop. The vagina may be absent or shorter than normal. A remnant of the uterus or uterine horns may be present [7].

\section{Aetiology}

Although cases of the syndrome are sporadic, there are cases that have a genetic link. Research shows that there may be a genetic component with deletions on chromosomes 1,4 , 8, 16, 17or 22 [8]. Duplication was also noted on chromosome $\mathrm{X}$. Partial duplication of SHOX gene is found in some cases for MRKH [9]. Loss of function on the WNT4 gene has also been considered [10].

\section{Anatomical Abnormalities}

The predominant effect is in the genitourinary system; however, the syndrome may affect additional systems besides the genitourinary tract as some have alopecia arreata or hirsutism [11,12] Cardiac abnormalities have also been noted $[13,14]$. Other cases have been described with auditory, skeletal, hematologic and endrocrine abnormalities such as diabetes and hyperprolactinemia [12,15-20]. The syndrome may also be associated with fibroids in the rudimentary uterus [21]. One case reports a possible association with metastatic papillary adenocarcinoma carcinoma [5].

\section{Investigations}

A hormonal assay (including but not limited to; testosterone, oestrogen, FSH \& LH and other tests to rule out differentials should be requested, guided by clinical presentation. Imaging studies are essential to assist with outlining the abnormalities present in the genitourinary tract. Ultrasound and MRI are some options. In most settings, ultrasound is available. However, it has its limitations as it may not identify underdeveloped mullerian structures and extra pelvic ovaries. MRI is the imaging of choice as it closely correlates with surgical findings $[22,23]$. But it is more expensive than ultrasound and not readily accessible in all clinical settings. 


\section{Treatment and Management}

The treatment of the syndrome involves a multidisciplinary approach with emphasis on treating each aspect of the syndrome. Counselling should be used to address the emotional and psychological components of MRKH [24]..

Nonsurgical and surgical options are available for the treatment of the physical aspect of the syndrome [25]. Non-functional uterine remnants may have to be resected laparoscopically. A neovagina may be created to facilitate sexual activity. A non surgical approach may be achieved by the Frank Procedure or Ingram's Method which entails use of dilators [26]. In one reported series $90 \%-95 \%$ of patients were able to achieve anatomic and functional success $[27,28]$.

The surgical method is the creation of a neovagina via open, laparoscopic or robotic techniques [29,33]. Surgical methods include the older procedures such as McIndoe procedure and the Williams procedure [34] using a split thickness skin graft and vulval flap respectively and new laparoscopic techniques include the Vecchietti procedure, using single peritoneal flap (SPF) and Davydov's laparoscopic technique [35]. The tissues used may beautologo us or biologically engineered [36,37].

It is important that these patients be screened for human papilloma virus once they are sexually active [38]. Postsurgical complications may be encountered such as necrosis of the vagina or vault prolapse [39-41]. Patients that want to pursue childbearing will require the assistance of reproductive technology [42].

\section{Summary}

MRKH although rare, we are learning more about the syndrome, the causative molecular genetics, how to diagnose it and the subsequent management. The options exist for non surgical and surgical management of the syndrome. All options should be reviewed with the patient to facilitate function and improve patient overall satisfaction with the outcome of the treatment. In terms of fertility, options will depend on the initial organs that are present and their function, such as use of autologous oocytes via a surrogate carrier. However, with continued expansion in the reproductive and endocrine and infertility arena additional options may soon be readily at hand such as uterine transplant.

\section{References}

1. Griffin JE (1976) Congenital absence of the vagina, The MayerRokitansky-Kuster-Hauser syndrome. Ann Intern Med 85(2): 224-236.

2. Morcel K, Camborieux L, Guerrier D (2007) Mayer-Rokitansky-KusterHauser (MRKH) Syndrome. Orphanet J Rare Dis 2: 13.

3. Ghirardini G, Popp LW (1995) The Mayer-von Rokitansky-KusterHauser Syndrome (uterus Bipartitus Solidus Rudimentarius Cum Vagina Solid): The Development of Gynecology through the History of a name. Clin Exp Obstet Gynecol 22(1): 86-91.

4. Pittock ST, Babovic-Vuksanovic D, Lteif A (2005) Mayer-Rokitansky-
Kuster-Hauser Anomaly and its Associated Malformations. Am J Med Genet A 135(3): 314-316.

5. Brown RJ, Petit JH, Widdel 1,Huquelet PS, Weekes C (2016) Metastatic Papillary Adenocarcinoma in a 22-Year-Old: Is Her History of MayerRokitansky-Kuster-Hauser Syndrome Causative or Incidental? Oncology (Williston Park) 30(12).

6. Varner RE, Younger JB, Blackwell RE (1985) Mullerian dysgenesis. J Reprod Med 30(6): 443-450.

7. Wright JE (1984) Failure of mullerian duct development. The MayerRokitansky-Kuster-Hauser syndrome. Aust Paediatr J 20(4): 325-327.

8. Bernardini L, Gimelli S, Gervasini C, Carella M, Babon A, et al. (2009) Recurrent microdeletion at 17q12 as a cause of Mayer-RokitanskyKuster-Hauser (MRKH) syndrome: two case reports. Orphanet J Rare Dis $4: 25$.

9. Gervasini C, Grati FR, Lalatta F, Tabono S, Gentillin B, et al. (2010) SHOX duplications found in some cases with type I Mayer-RokitanskyKuster-Hauser syndrome. Genet Med 12(10): 634-640.

10. Biason-Lauber A, DE Filippo G, Konrad D, Scarano G, Nazzoro A, et al. (2007) WNT4 deficiency--a clinical phenotype distinct from the classic Mayer-Rokitansky-Kuster-Hauser syndrome: a case report. Hum Reprod 22(1): 224-229.

11. Choudhary SV, Choudhari UV (2016) Mayer-Rokitansky-Kuster-Hauser Syndrome with Alopecia: A Rare Case Report with Review of Literature. Int J Trichology 8(3): 141-143.

12. Sandeep Arora S, SPS Kochar, Gulhima Arora, Diwakar D (2014) Undiagnosed Hirsutism Associated Mayer-Rokitansky-Kuster-Hauser Syndrome in Dermatology OPD. Indian J Dermatol 59(6): 623-625.

13. Biecker A, Willinek WA, Grohe C (2006) Mayer-Rokitansky-KusterHauser syndrome with aortic isthmus stenosis. Duetsche Medizinesche Wochenscrift 131(11): 540-542.

14. Bailey AP, Young JL, Nigrini E, Modesitt SC (2010) Anomalous vasculature in Mayer-Rokitansky-Kuster-Hauser syndrome. Fertil Steril 94(1): 350 e1-4.

15. Ahmad R, Pope S (2008) Association of Mayer-Rokitansky-KusterHauser syndrome with Thrombocytopenia Absent Radii syndrome: a rare presentation. Eur J Obstet Gynecol Reprod Biol 139(2): 257-258.

16. Al-Jaroudi DH, Nasser AM (2008) Mayer-Rokitansky-Kuster-Hauser syndrome with hyperprolactinemia. Saudi Med J 29(6): 901-903.

17. Bellver-Pradas J, Cervara-Sanchez, Boldo-Roda A, Martin-Cortes A, Fererres-Gomez L, et al. (2001) Silver-Russell syndrome associated to Mayer-Rokitansky-Kuster-Hauser syndrome, diabetes and hirsutism. Arch Gynecol Obstet, 265(3): 155-157.

18. Bjorsum-Meyer T, Herlin M, Qvist N, Micheal B Peterson (2016) Vertebral defect, anal atresia, cardiac defect, tracheoesophageal fistula/esophageal atresia, renal defect, and limb defect association with Mayer-Rokitansky-Kuster-Hauser syndrome in co-occurrence: two case reports and a review of the literature. J Med Case Rep 10(1): 374.

19. Borges Mde A, Pires ML, Monteiro DL, Santos SR (2012) Atipical form of Mayer-Rokitansky-Kuster-Hauser syndrome with renal malformation and skeletal abnormalities (MURCS association)]. Rev Bras Ginecol Obstet 34(3): 133-138.

20. M Akcay (2016) Percutaneous closure of isolated ostium secundumtype atrial septal defect in a patient with Mayer-Rokitansky-KusterHauser syndrome. Rev Port Cardiol 35(12): 701.e1-701.e3.

21. PS Hoo, Norhaslinda AR, Shah Reza JN (2016) Rare Case of Leiomyoma and Adenomyosis in Mayer-Rokitansky-Kuster-Hauser Syndrome. Case Reports in Obstetrics Gynecology Article ID 3725043. 
22. Fiaschetti V, Taglieri A, Giosnee V, Coco I, Simonetti G (2012) MayerRokitansky-Kuster-Hauser syndrome diagnosed by magnetic resonance imaging. Role of imaging to identify and evaluate the uncommon variation in development of the female genital tract. J Radiol Case Rep 6(4): 17-24.

23. Preibsch H, Ket R, Wietek BM, Brucker SY, Steabler A,et al. (2014) Clinical value of magnetic resonance imaging in patients with MayerRokitansky-Kuster-Hauser (MRKH) syndrome: diagnosis of associated malformations, uterine rudiments and intrauterine endometrium. Eur Radiol 24(7): 1621-1627.

24. Fliegner M, Krupp K, Brunner F, Rall k, Brucker SY, et al. (2013) Sexual life and sexual wellness in individuals with complete androgen insensitivity syndrome (CAIS) and Mayer-Rokitansky-Kuster-Hauser Syndrome (MRKHS). J Sex Med 11(3): 729-742.

25. Marin JS, Lara LA, da Silva AV, dos Ries RM, Junqueira FR, et al. (2012) Surgical and non-surgical treatment of vaginal agenesis: analysis of a series of cases. Rev Bras Ginecol Obstet 34(6): 274-277.

26. Mee Hwa Lee (2006) Non-surgical treatment of vaginal agenesis using a simplified version of Ingram's method. Yonsei Med J 47(6): 892-895.

1. 27. Edmonds DK, Rose GL, Lipton MG, Quek J (2012) MayerRokitansky-Kuster-Hauser syndrome: a review of 245 consecutive cases managed by a multidisciplinary approach with vaginal dilators Fertil Steril 97(3): 686-690.

27. Roberts CP, Haber MJ, Rock JA (2001) Vaginal creation for mullerian agenesis. Am J Obstet Gynecol 185(6): 1349-1352.

28. Busacca M, Perino A, Venezia R (1996) Laparoscopic-ultrasonographic combined technique for the creation of a neovagina in MayerRokitansky-Kuster-Hauser syndrome. Fertil Steril 66(6): 1039-1041.

29. Cai B, Zhang JR, Xi XW, Yan Q, Wan XP (2007) Laparoscopically assisted sigmoid colon vaginoplasty in women with Mayer-Rokitansky-KusterHauser syndrome: feasibility and short-term results. BJOG 114(12): 1486-1492.

30. Cetin C, Soysal C, Urunsak IF, Api M, Cetin T (2016) Long-Term Outcomes of Laparoscopic Bean Vaginoplasty (Modified Vecchietti Procedure) for Mayer-Rokitansky-Kuster-Hauser Syndrome. J Laparoendosc Adv Surg Tech A 26(8): 591-595.

31. Boztosun A, Olqan S (2016) Robotic Sigmoid Vaginoplasty in an Adolescent Girl With Mayer-Rokitansky-Kuster-Hauser Syndrome. Female Pelvic Med Reconstr Surg 22(5): e32-e35.
32. Berry T, Tapera C, Gur U, Fabriozio M, Jordon G (2008) Robot-assisted vaginal construction using ileum in a case of Mayer-Rokitansky-KusterHauser syndrome. J Robot Surg 2(4): 243-246.

33. Ben Hmid R, Touhami O, Zouaiui B, Ben Amara F, Zghal D (2012) Evaluation of different techniques for vaginoplasty in the treatment of Mayer-Rokitansky-Kuster-Hauser syndrome. Tunis Med 90(12): 852855.

34. Zhao X, Wang R, Wang Y, Li L, Zhanq H, et al. (2015) Comparison of two laparoscopic peritoneal vaginoplasty techniques in patients with Mayer-Rokitansky-Kuster-Hauser syndrome. Int Urogynecol J 26(8): 1201-1207.

35. Benedetti Panici P, Maffucci D, Ceccarwelli S, Vescarelli E, Perniola G, et al. (2015) Autologous in vitro cultured vaginal tissue for vaginoplasty in women with Mayer-Rokitansky-Kuster-Hauser syndrome: anatomic and functional results. J Minim Invasive Gynecol, 22(2): 205-211.

36. Zhu L, Zhou H, Sun Z, Lou W, Lang J, et al. (2013) Anatomic and sexual outcomes after vaginoplasty using tissue-engineered biomaterial graft in patients with Mayer-Rokitansky-Kuster-Hauser syndrome: a new minimally invasive and effective surgery. J Sex Med 10(6): 1652-1658.

37. Frega A, Scripa P, Sopracardevole F, Biomonti A, Bianchi P, et al. (2011) Impact of human papillomavirus infection on the neovaginal and vulval tissues of women who underwent surgical treatment for MayerRokitansky-Kuster-Hauser syndrome. Fertil Steril 96(4): 969-973.

38. Zhu L, Chen N, Lang J (2013) Vault prolapse of sigmoid neovagina 26 years after vaginoplasty in Mayer-Rokitansky-Kuster-Hauser syndrome: a case report. Int Urogynecol J 24(1): 179-180.

39. Yokomizo R, Murkomi T, Noitou H, Yamada A (2002) Treatment for prolapse of the sigmoid neovagina in Mayer-Rokitansky-Kuster-Hauser syndrome. Obstet Gynecol 100(5 Pt 2): 1085-1087.

40. Calcagno M, Pastore M, Bellati F, Plotti F, Maffucci D, et al. (2010) Early prolapse of a neovagina created with self-dilatation and treated with sacrospinous ligament suspension in a patient with Mayer-RokitanskyKuster-Hauser syndrome: a case report. Fertil Steril 93(1): 267 e1-4.

41. Ben-Rafael Z, Bar-Hava I, Levy T, Orevito R (1998) Simplifying ovulation induction for surrogacy in women with Mayer-Rokitansky-KusterHauser syndrome. Hum Reprod 13(6): 1470-1471.

\section{Your next submission with Juniper Publishers will reach you the below assets}

- Quality Editorial service

- Swift Peer Review

- Reprints availability

- E-prints Service

- Manuscript Podcast for convenient understanding

- Global attainment for your research

- Manuscript accessibility in different formats

( Pdf, E-pub, Full Text, Audio)

- Unceasing customer service

Track the below URL for one-step submission https://juniperpublishers.com/online-submission.php 